\title{
Study on the Setting and Arrangement of Art Courses for Preschool Education Major
}

\author{
Jing Lei \\ Department of Humanities and International Education, Xi'an Peihua University, Xi 'an, Shaanxi \\ Province, China
}

\begin{abstract}
Art course is a very important compulsory art course for preschool education majors. It is also a professional art education course to cultivate students' basic art skills and comprehensive artistic quality. This course enables students to improve their cognitive ability, modeling ability, aesthetic ability and practical ability on the premise of understanding and mastering basic art knowledge and basic skills. Students in the development and improvement of artistic literacy, but also can improve the aesthetic awareness of plastic arts, in order to provide the necessary conditions for further learning related pre-school education knowledge. This course aims at improving students' professional quality and lays a good foundation for training excellent preschool education preschool teachers with strong artistic quality and comprehensive ability. Therefore, the study of art curriculum is an important link to promote the design and development of preschool education specialty. This paper will make a specific analysis of the setting and arrangement of art curriculum for preschool education specialty.
\end{abstract}

Keywords: preschool education, art courses, settings, arrangements.

\section{Course Orientation}

\subsection{Course's Position and Function in Professional Training}

This course is a very important compulsory art course for preschool education majors. It is also a professional art education course to cultivate students' basic art skills and comprehensive artistic quality. This course enables students to improve their cognitive ability, modeling ability, aesthetic ability and practical ability on the premise of understanding and mastering basic art knowledge and basic skills. Students in the development and improvement of artistic literacy, but also can improve the aesthetic awareness of plastic arts, in order to provide the necessary conditions for further learning related pre-school education knowledge. This course aims at improving students'professional quality and lays a good foundation for training excellent preschool education preschool teachers with strong artistic quality and comprehensive ability. Therefore, the study of art course is an important link to promote the design and development of preschool education specialty.

\subsection{Teaching Objectives}

Through the study of this course, the students will have a preliminary understanding of the aims of art and education, make clear the basic laws and principles of aesthetics, and understand and master the general laws, methods and basic knowledge and skills of art activities. Through the study of art courses, students should master the way of thinking in images, study art language, form the understanding and understanding of the elements of modelling, learn the basic skills of art creation, develop and improve their artistic accomplishment, and cultivate their love for art. In the future, art knowledge and skills can be applied to pre-school education and teaching activities, so that art education can play a role in the development of children's intellectual skills in the future pre-school education work.

\subsection{The Relationship between this Course and Other Courses}

As a compulsory course in preschool education, art curriculum is closely related to such subjects as Art Theory, Art Education, Music, Dance, Literature and Philosophy. In addition, this course provides a technical basis for the later courses such as "Kindergarten Play Instrument Production" and "Kindergarten Environment Creation". 


\section{Examination Methods}

This course adopts the process assessment method, and the process examination results account for $100 \%$ of the total score, of which attendance is 10 points, classroom performance and Practice 10 points, after-school assignments 40 points, large works show 40 points, and the total score is 100 points.

Examination contents include sketch, sketch, children's painting, scraping, printmaking, decorative painting and traditional Chinese painting. The time of assessment is divided into normal assessment and final assessment, which is completed in class at ordinary times. At the end of the term, students are asked to submit large-scale works and display their works.

\section{Outline of Main Teaching Contents}

Chapter I "Introduction to Fine Arts", teaching objectives and requirements are: 1. Understanding the concept, classification, language and value of fine arts. 2. Master the method of appreciation of art works. 3. Master different perspectives of art appreciation. The teaching emphasis is: the basic concept of fine arts and the classification of fine arts. The difficulty of teaching is: art language and art value. The knowledge and skills of teaching include the concept of fine arts, children's fine arts and appreciation of fine arts works.

Chapter II "Basic Knowledge and Perspective of Sketch", teaching objectives and requirements are: 1. Understanding the basic knowledge of sketch. 2. Understand the correct observation method of sketch. 3, grasp the perspective principle of sketch. The key point of teaching is to understand sketch with correct observation method. The difficulty of teaching is to grasp the perspective principle of sketch. The points and points of knowledge in teaching are: basic knowledge of drawing, drawing of lines, expression of light and shade, and principle of perspective.

Chapter III "Gypsum Geometry Training", teaching objectives and requirements are: through learning the structure of geometry and the relationship between light and shade more profound understanding of the drawings of the existing problems. For example, the perspective of geometry, the black-white-grey relationship of objects. The key point of teaching is to master the three-point perspective of gypsum geometry and the law of light and shade change through the study of gypsum geometry. The difficulties of teaching are to grasp the perspective principle and the performance of light and shade. The knowledge points and skill points of teaching are: copying and sketching of the combination of cube, vertebral body, sphere and geometric body.

Chapter IV "Basic Sketch Knowledge and Perspective", teaching objectives and requirements are: 1. Through appreciation and observation of physical objects, stimulate students'enthusiasm for painting. 2. By learning and mastering the basic knowledge of sketch in the first stage, we can understand and master it through practice. The key point of teaching is to review the sketch knowledge and apply it to color lead sketch sketch sketch students. The difficulty of teaching is the transition from sketch to color lead sketch. The points and points of knowledge in teaching are: color lead still life sketch, color lead flower drawing, color lead animal drawing, color lead drawing combination sketch and creation.

Chapter V "Simple Brush Painting", teaching objectives and requirements are: to understand the characteristics and rules of the shape of simple brush painting, skillfully grasp the painting skills of simple brush painting, to achieve a certain degree of application ability. The teaching emphasis is: the characteristics and rules of the simple strokes. The difficulty of teaching is: the method and law of simple strokes. The knowledge and skills of teaching include: plant, vegetable, fruit, living utensils, transportation, architecture, animals, insects, figures, etc.

Chapter VI "Children's Figure Painting and Cartoon Painting", teaching objectives and requirements are: through learning the types of children's story illustrations, basic drawing methods and the creation of single and multiple children's story illustrations, children's figure painting and cartoon creation can be carried out. The key points of teaching are: the basic characteristics of children's figure painting and cartoon painting. Difficulties in teaching are: different types of 
children's figure painting and cartoon painting and different techniques of expression. The knowledge and skills of teaching are: children's figure painting training, cartoon creation.

Chapter 7 "Composition", teaching objectives and requirements are: 1 . Under the condition of twodimensional plane, learning and observation, the proportion of the image, basic shape summary and other elements of plane modeling. 2. Learn to observe and express as a whole. The emphasis of teaching is the observation and expression of the whole object. The difficulties in teaching are: the basic shape generalization of objects and the expression of plane and color. The knowledge points and skill points of teaching are plane composition, design and drawing of color composition.

Chapter 8 "Oil Painting Sticks", teaching objectives and requirements are: to understand and master the performance and painting skills of crayons and oil painting sticks, and to cultivate students'proficiency in using the above paintbrushes to draw and create children's paintings. The key point of teaching is to master crayon and oil painting stick painting skills. The difficulties in teaching are: the ability to draw and create children's paintings and scratches with crayons and oil sticks. The knowledge and skills of teaching are scraping and making.

Chapter 9 "Printing", teaching objectives and requirements are: to understand and master the tools and materials of paper printmaking and blow-moulding paper engraving, production steps and the effect of artistic treatment, and to cultivate students'practical ability. The key point of teaching is to master the production steps of various paper prints and the effect of artistic treatment. The teaching difficulties are: the production steps of various paper prints and the effect of artistic treatment. Teaching knowledge and skills are black and white prints, color prints production.

Chapter 10 "Decorative Painting", teaching objectives and requirements are: to learn the basic knowledge of color, color emotion, color performance, master the application skills of decorative color painting, in order to improve students'ability to express color and aesthetic level. The key point of teaching is the technique of expression of decorative color. The difficulty of teaching is the formal law of decorative color. The knowledge and skills of teaching are: the creation of wood decoration painting, stone decoration painting, paper plate decoration painting and spoon decoration painting.

Chapter 11 "Li Fen Painting", teaching objectives and requirements are: through the composition, color, shape of Li Fen decorative painting learning, combined with the performance techniques of $\mathrm{Li}$ Fen decorative painting, can basically master the performance and techniques of Li Fen decorative painting. The key points of teaching are: the basic characteristics of composition, shape and color of Li Fen decorative painting. Difficulties in teaching are: different kinds of leachate decorative paintings and different performance techniques. The knowledge and skill points of teaching are as follows: the appreciation of decorative painting with leachate powder and the creation of decorative painting with leachate powder.

Chapter 12 "Children's Story Illustration Creation", teaching objectives and requirements are: 1. Understanding the formation and development of cartoons, cartoon artistic characteristics. 2. Grasp the modeling characteristics of cartoon painting and the expressive methods and steps of cartoon figure painting. The emphasis of teaching is: the expressive methods and steps of cartoon figure painting. The difficulties in teaching are: designing animated cartoon characters'action drawings and creating children's cartoon drawings. The knowledge and skill points of teaching are: the basic knowledge of children's story illustration creation, and the training of children's story illustration creation.

Chapter 13 "Children's Story Illustration Creation", teaching objectives and requirements are: learning the place, type, characteristics and design principles of kindergarten mural wall decoration, how to apply these principles to design and draw excellent wall decoration works. The teaching emphasis is: the place, type, characteristics and design principles of wall decoration. Teaching difficulties are: how to design and draw excellent wall decoration works. The points and points of knowledge in teaching are: Animal wall decoration, character wall decoration.

Chapter 14 "Traditional Chinese Painting", teaching objectives and requirements are: learning to master the creative methods of traditional Chinese painting. The key point of teaching is to master the expression method of Chinese painting. The difficulty in teaching is the application of expressive 
techniques. The knowledge and skills of teaching are: basic knowledge of Chinese painting, fine brushwork and freehand brushwork.

\section{Summary}

The teaching content of this course is arranged according to the progress of the curriculum, from simplicity to difficulty, step by step, and gradually learning. Teaching methods should adopt a variety of teaching methods, so as to combine theory with practice. Teaching teams should cooperate with each other, communicate with each other, prepare lessons collectively, and arrange teaching progress uniformly. The teaching implementation of this course should make full use of the resources in the school to teach and create good teaching conditions for students'learning.

\section{References}

[1]. Wang Qimin. Sketch introduction: [M]. Beijing: People's fine arts publishing house, 1996.

[2]. Yu Le Xiao. Applied Arts [M]. Shanghai: Higher Education Press, 1991.

[3]. Li Xueying. Practical arts foundation [M].:: Fine Arts Publishing House, 1987.

[4]. Zhang Zhao Ji. Painting (1) [M].:: Publishing House, 2013.

[5]. Zhang Zhaoji, Zhao Zhongqi. Painting (two) [M].: Publishing House, 2013.

[6]. Zhang Zhaoji, Teng Jian Zhi. Painting (three) [M]. Shanghai: Fudan University press, 2013.

[7]. Yang Jingzhi. Art education and human development -- Research on teaching methods of children's art [M].: People's fine arts publishing house, 1999.

[8]. Cao Wei Ye. Art curriculum and teaching theory [M]. Guangzhou: Guangdong higher education press, 2014.

[9]. Shaw, Zeng Xiaohong. Children's art education theory and teaching guidance [M].:: Publishing House, 2017. 